\title{
Response of broiler chickens to feed restriction during brooding under tropical conditions
}

\author{
A.Téguia', J. Awah Ndukum and S.B. Kouomou \\ Department of Animal Science, Faculty of Agriculture and Agricultural Sciences, \\ University of Dschang \\ POB 70, Dschang, Cameroon
}

(Received 25 June 2001; revised version 16 Octobre 2001; accepted 31 January 2002)

\begin{abstract}
Two hundred broiler chickens were used to study the effect of feed restriction from 5 to 8 or 9 days of age on their subsequent production performance. Birds were randomly distributed to four treatment groups. In two groups, birds were fed a conventional broiler starter diet from 0 to 4 days and were fasted for 3 (T1) or 4 (T2) days. Birds in group T3 were fed exclusively broken maize until 4 days of age and then were fasted for 3 days. Thereafter, all feed restricted birds were fed the conventional starter and finisher diets. Control group (T0) was given the conventional broiler diets throughout the whole experimental period. During the starter period, feed restriction significantly $(\mathrm{P}<0.05)$ depressed body weight gain, particularly before 14 days of age. By 42 days of age, the birds from groups $\mathrm{T} 1$ and $\mathrm{T} 2$ had recovered body weights, except those started on broken maize that had lower body weight $(\mathrm{P}<0.05)$. Following feed restriction birds utilized feed more efficiently $(\mathrm{P}<0.01)$ than control birds, indicating on some compensatory growth. Carcass characteristics were not affected by the feed restriction.

It was concluded that broiler chickens could withstand 3 or 4 days of fasting in early life without any negative effect on the production performance and that quality of feed before fasting and duration of feed restriction influence recovery.
\end{abstract}

KEY WORDS: broiler chickens, feed restriction, feed efficiency, carcass characteristics

\section{INTRODUCTION}

Broiler chickens are voracious eaters if fed ad libitum and over $70 \%$ of the production cost of commercial poultry farms is feed. High feed consumption, though playing an important role in the increase in growth rate, could result in increased fat

\footnotetext{
' Corresponding author
} 
deposition and high incidence of skeletal and metabolic disorders (Leeson and Summers, 1988). Various measures have been studied to significantly reduced production cost especially of feed, while improving productivity. Slower growth rate due undernutrition or energy intake limited to maintenance requirement only for a short period early in life can greatly reduce the incidence of metabolic disorders, improve skeletal development and limit fat deposition. In broiler chickens Leeson et al. (1991) reported a reduction of body weight after undernutrition period, throught diet dilution, from 4 to 11 days of age and a complete recovery of body weight by 42 days of age when birds were fed conventional diets. However, in this experiment meaningful reduction of abdominal fat by 42 days was observed. In a similar study, Leeson and Zubair (1997) also found that broiler birds were not able to recover from body weight depression by 21 days although the restricted birds were more efficient in utilization of energy. Energy restriction during brooding may be associated with reductions in fat anabolism while the optimum market weight is attributed to the subsequent compensatory growth during refeeding. Although energy restriction through diet dilution during finishing of broilers is known to significantly reduce abdominal fat content without influencing carcass quality (Leeson et al., 1992), diet dilution early in the life of broiler birds seems not to affect fat deposition. Fasting of chickens in an earlier stage of their life could have a more beneficial effect on fat deposition and compensatory growth of broiler birds.

This study was therefore carried out to study the effect of early life feed restriction imposed through complete restriction for 3 or 4 days on the productivity of Arbor Acres broiler chickens.

\section{MATERIAL AND METHODS}

\section{Animals and diets}

Two hundred day-old unsexed Arbor Acres chickens weighing about $50 \mathrm{~g}$ each were used. The birds were vaccinated against Newcastle, infectious bronchitis and Gumboro diseases. Coccidiostatics were distributed for 3 days from day 15 and every week thereafter. The birds were administered antistress agents before and after each vaccination and after each transfer.

The day-old chickens were randomly distributed into 4 groups (T0, T1, T2 and T3), each represented by 10 birds in 5 replicate bamboo cages and started according to usual brooding practices. At the end of a 28-day starter period, the birds of each group were transferred into Californian type cages and housed in pairs including one male and one female, for the finisher period.

From 1 to 4 days of age, groups T0, T1 and T2 were fed ad libitum with the usual starter diet (ME $2969 \mathrm{kcal} / \mathrm{kg}$; crude protein, 21.5\%; Ca, 1.60\%; P, 0.70\%) 
while group T3 was exclusively fed broken maize (ME $3432 \mathrm{kcal} / \mathrm{kg}$; crude protein, $8.5 \% ; \mathrm{Ca}, 0.02 \% ; \mathrm{P}, 0.25 \%)$. Thereafter, birds of groups $\mathrm{T} 1$ and $\mathrm{T} 3$ and were fasted for 3 days (from 5 to 8 days of life) and of group T2 for 4 days (from 5 to 9 days of life). After the fasting period, birds in all three groups were refed ad libitum with the starter diet till 28 days of age and the finisher diet (ME $2983 \mathrm{kcal} / \mathrm{kg}$; crude protein, $18.7 \% ; \mathrm{Ca}, 0.82 \% ; \mathrm{P}, 0.62 \%$ ) till 49 days of age. Birds in the control group (T0) were fed ad libitum with the starter and finisher diets.

Water was freely available to all the birds during the experiment, including the feed restriction period.

\section{Collection and analysis of data}

Birds were weighed and feed intake was recorded at weekly intervals. Body weight gain and feed conversion ratio were calculated. At the end of the study, 4 birds ( 2 males and 2 females) per treatment group were randomly selected to evaluate the carcass quality according to Jourdain (1980).

The data were analysed using a one-way analysis of variance (ANOVA). The extend of dispersion between the means of the response variables were submitted to the Duncan's multiple range test (Steel and Torrie, 1980).

Estimates of production cost for one $\mathrm{kg}$ of poultry meat were done using feed consumption as the only variable. The cost of production was obtained by multiplying the cost of $1 \mathrm{~kg}$ of feed by the feed efficiency ratio of each treatment group.

\section{RESULTS}

The effect of feed restriction on body weight and body weight gain are presented in Tables 1 and 2. Feed restriction significantly $(\mathrm{P}<0.05)$ depressed body weight gain during the starter period. The reduction was most pronounced before 14 days of age and amounted 15,25 and 45\%, respectively for birds on treatments $\mathrm{T} 1, \mathrm{~T} 2$ and $\mathrm{T} 3$ as compared with the control group (T0). Compensatory growth was evident for these birds from 28 to 42 days of age and by 42 days of age, all the bird, except those that were started on broken maize before feed restriction, had comparable body weight. Body weight gain of $\mathrm{T} 3$ feed restricted birds was significantly $(\mathrm{P}<0.05)$ lower than that of birds on control diet $(\mathrm{T} 0)$ during the 28 to 49 day period, while the T0, T1 and T2, birds had comparable body weight gain.

Over the starter period, feed restriction of birds through fasting for 3 to 4 days resulted in significantly $(\mathrm{P}<0.05)$ decreased feed intake (Table 3$)$ in comparison with the control group. The decrease in feed intake among the feed restricted birds was most pronounced before 14 days of age, being least with T3 $(50 \%)$ followed by T2 (29\%) and T1 group (17\%). However, during the $28-49$ day finisher period, 
TABLE 1

Body weight of broiler chickens subjected to feed restriction from 5 to 9 days of age, $g$

\begin{tabular}{lccccc}
\hline \multirow{2}{*}{ Treatments } & \multicolumn{5}{c}{ Age, days } \\
\cline { 2 - 6 } & 7 & 14 & 28 & 42 & 49 \\
\hline Control (T0) & $113^{\mathrm{a}}$ & $274^{\mathrm{a}}$ & $701^{\mathrm{a}}$ & $1350^{\mathrm{a}}$ & $1919^{\mathrm{a}}$ \\
T1 & $89^{\mathrm{b}}$ & $241^{\mathrm{b}}$ & $644^{\mathrm{ab}}$ & $1348^{\mathrm{a}}$ & $1924^{\mathrm{a}}$ \\
T2 & $63^{\mathrm{c}}$ & $217^{\mathrm{a}}$ & $656^{\mathrm{ab}}$ & $1368^{\mathrm{a}}$ & $1954^{\mathrm{a}}$ \\
T3 & $70^{\mathrm{b}}$ & $183^{\mathrm{b}}$ & $583^{\mathrm{b}}$ & $1284^{\mathrm{b}}$ & $1810^{\mathrm{b}}$ \\
SEM & 4.34 & 5.20 & 21.58 & 20.02 & 32.85 \\
\hline
\end{tabular}

a.b.c means with the same letter in a column are not significantly different at $\mathrm{P}>0.05$

SEM: standard error of the mean

TABLE 2

Body weight gain of broiler chickens subjected to feed restriction from 5 to 9 days of age, $g$

\begin{tabular}{llllllc}
\hline \multirow{2}{*}{ Treatments } & \multicolumn{7}{c}{ Age period, days } \\
\cline { 2 - 6 } & 1 to 14 & 14 to 28 & 28 to 42 & 42 to 49 & 1 to 28 & 28 to 49 \\
\hline Control (T0) & $223^{\mathrm{a}}$ & $427^{\wedge \mathrm{B}}$ & $649^{\mathrm{a}}$ & $569^{\text {ab }}$ & $651^{\mathrm{a}}$ & $1218^{\text {ath }}$ \\
T1 & $191^{\mathrm{b}}$ & $404^{\mathrm{AC}}$ & $704^{\text {ah }}$ & $575^{\text {ab }}$ & $594^{\mathrm{a}}$ & $1278^{\text {ah }}$ \\
T2 & $166^{\mathrm{c}}$ & $439^{\mathrm{B}}$ & $712^{\mathrm{h}}$ & $586^{\mathrm{a}}$ & $605^{\mathrm{a}}$ & $1298^{\mathrm{a}}$ \\
T3 & $133^{\mathrm{a}}$ & $400^{\mathrm{C}}$ & $702^{\mathrm{b}}$ & $522^{\mathrm{b}}$ & $533^{\mathrm{b}}$ & $1198^{\mathrm{b}}$ \\
SEM & 5.20 & 18.74 & 20.01 & 22.43 & 22.17 & 34.48 \\
\hline
\end{tabular}

a.b.c means with the same tetter in a column are not significantly different at $P>0.05$

A.B.C $P>0.01$

SEM: standard error of the mean

birds in treatments $\mathrm{T} 1$ and $\mathrm{T} 2$ consumed more $(\mathrm{P}<0.05)$ feed compared to the control and T3 groups.

Birds on treatment $\mathrm{T} 3$ exhibited the poorest $(\mathrm{P}<0.01)$ feed efficiency during the 0-28 day, however, there was no difference between T3 and the control group for feed efficiency ratio. Over the 28 to 49 day period, 3 or 4 days of fasting did not affect feed efficiency ratio ( $\mathrm{P}>0.05$; Table 3 ).

Carcass characteristics were not affected by feed restriction which was significantly $(\mathrm{P}<0.05)$ lower in $\mathrm{T} 2$ and $\mathrm{T} 3$ groups with exception of abdominal fat content (Table 4).

Simple cost estimates for the production of one kg of poultry meat in this study revealed a cost reduction of $0.5,2.3$ and $1.4 \%$ for birds on treatments $\mathrm{T} 1, \mathrm{~T} 2$ and T3, respectively compared to the control. 
TABLE 3

Feed intake and feed conversion ratio ( $\mathrm{g}$ feed $\mathrm{g}^{\prime}$ gain) of broiler chickens subjected to feed restriction from 5 to 9 days of age, $g$

\begin{tabular}{|c|c|c|c|c|c|c|}
\hline \multirow{2}{*}{ Treatment } & \multicolumn{3}{|c|}{ Feed intake } & \multicolumn{3}{|c|}{ Feed conversion ratio } \\
\hline & starter & finisher & total & starter & finisher & total \\
\hline Control (TO) & 1304 & $2661^{: t}$ & 3964 & $2.01^{A B}$ & $2.21^{\sharp}$ & $2.13^{i}$ \\
\hline $\mathrm{T} \mathbf{l}$ & $1173^{b}$ & $2814^{b}$ & $3954^{a}$ & $1.99^{\mathrm{A}}$ & $2.23^{\mathrm{a}}$ & $2.12^{2}$ \\
\hline $\mathrm{T} 2$ & $1172^{b}$ & $2793^{b}$ & $3965^{\prime \prime}$ & $1.94^{\wedge}$ & $2.16^{4}$ & $2.08^{u}$ \\
\hline T3 & $1082^{c}$ & $2589^{a}$ & $3671^{b}$ & $2.05^{\mathrm{B}}$ & $2.19^{4}$ & $2.10^{\mathrm{a}}$ \\
\hline SEM & 31.51 & 43.23 & 47.64 & 0.08 & 0.06 & 0.04 \\
\hline
\end{tabular}

a.b.c as in Table 1

TABLE 4

Carcass yield without giblets (\% liveweight) and carcass characteristics (\% carcass weight) of broiler chickens subjected to feed restriction from 5 to 9 days of age

\begin{tabular}{lcccc}
\hline Treatment & $\begin{array}{c}\text { Carcass } \\
\text { yield }\end{array}$ & Liver & $\begin{array}{c}\text { Abdominal } \\
\text { fat }\end{array}$ & Gizzard \\
\hline Control (T0) & 73.00 & 2.05 & $1.89^{\mathrm{a}}$ & 2.05 \\
T1 & 73.14 & 1.87 & $1.80^{\mathrm{a}}$ & 1.82 \\
T2 & 71.20 & 2.01 & $1.23^{\mathrm{b}}$ & 1.95 \\
T3 & 73.54 & 2.06 & $1.38^{\mathrm{b}}$ & 1.97 \\
SEM & 1.73 & 0.12 & 0.13 & 0.10 \\
\hline
\end{tabular}

u.b,c as in Table 1

\section{DISCUSSION}

Starting broiler chickens on a conventional starter diet or broken maize from 0 to 4 days of age followed by 3 or 4 days of fasting resulted in significant reduction in weight gain by 14 days of age. The effect at 28 days was less severe and there was a complete recovery for birds started on a conventional starter diet before fasting period. This indicated that there was some form of compensatory growth probably related to the modification of maintenance energy requirement and the improvement of the efficiency of feed utilization following feed restriction. Similar results have been reported by Leeson et al. (1991) after undernutrition of chickens from 4 to 11 days of age through diet dilution. It was observed that by 49 days of age birds started on broken maize before the fasting period (T3) had the lowest body weight compared with other feed restricted birds. This suggested the dependency of recovery time on the degree and severity of feed restriction. 
In the present study, there was a drop in feed intake immediately following complete feed restriction. Corresponding energy intakes were therefore expected to be reduced and the better feed efficiency of birds in T1 and T2 groups to 28 days of age confirmed the compensatory weight gain observed. The significant $(\mathrm{P}<0.05)$ increase in feed intake of birds in groups $\mathrm{T} 1$ and $\mathrm{T} 2$ and consequently the increase in their energy intake as compared to the $\mathrm{T} 3$ and control groups resulted in higher liveweight by day 49 . This indicated that following the modification of energy requirement for maintenance, more energy was probably directed towards lean body mass than fat deposition. This is confirmed by the reduction in abdominal fat of these birds. The present study is in agreement with report by Leeson and Zubair (1997) that by 21 days of age, broiler birds are not able to fully recover body weight depression although the feed restricted birds were more efficient in the utilization of energy intake. Leeson and Zubair (1997) stated that birds exhibit significantly improved feed efficiency irrespective of the method of nutrient restriction, physical restriction or diet dilution. However, the physical restriction carried out by these authors was partial $(50 \%)$ for 6 to 12 days of age and not a $100 \%$-fasting as in the present study. Birds started on broken maize and then fasted for 3 days (T3) consumed significantly less feed and had significantly lower weight gain than birds on the other groups. Broken maize as a starter diet not only is very deficient in vital nutrients, but also is not easily digested by young birds and could traumatise the digestive system of the chickens. This physical trauma together with the 3-day fasting could be largely responsible for the incomplete recovery of body weight of the T3 birds by 49 days of age.

In general, 49-day liveweight of birds in the present study was lower than that suggested by the hatchery and feed efficiency ratio, including the control group was poorer, suggesting extra-experimental factors. This could be related to the quality of the feed used and the fact that these chickens are initially produced for temperate areas.

The carcass quality was not affected by the early-life feed restriction carried out in the present study. The carcass yield recorded in the present study for all groups was higher than that mentioned by Jourdain (1980), but in the range suggested by Mountney (1981) for broiler chickens. As in the present study, earlier works did not report any meaningful difference in carcass fat proportion. This is thought to be related to reduced adipocyte hyperplasia, with the adipocytes remaining smaller or this could be due to the degree of energy restriction (Leeson et al., 1991) during the period of nutrient restriction.

The reduction in cost of feeding in treatment groups as compared to the control is probably related to better utilization of feed in feed restricted birds. Although not significant in the present study, the difference between the control group and the restricted one could be of prime practical importance as this could mean a sensible reduction in the cost of production, particularly in large production units. 


\section{CONCLUSIONS}

Broiler chickens can withstand a period of undernutrition early in life without significant loss in market weight, feed utilization efficiency or carcass quality. However, the advantages of such practice under commercial management conditions in the tropics will depend on the methods of feed restriction, duration and possible alterations in carcass quality. Under commercial conditions, feed restriction could be justified by a reduction in cost of feeding broiler chicken to market weight.

\section{REFERENCES}

Jourdain R., 1980. L’Aviculture en Milieu Tropical. Edition Sté Jourdain, Boissy Chatel, Paris

Leeson S., Summers J.D., 1988. Some nutritional implications of leg problems with poultry. Brit. Vet. J. $144,81-92$

Leeson S., Summers J.D., Caston L.J., 1991. Diet dilution an compensatory growth in brotlers. Poultry Sci. 70, 867-873

Leeson S., Summers J.D., Caston L.J., 1992. Response of broilers to feed restriction or diet dilution in the finisher period. Potltry Sci. 71, 2056-2064

Leeson S., Zubair A.K., 1997. Nutrition of broiler chicken around the period of compensatory growth. Poultry Sci. 76, 992-999

Mountney G.J., 1981. Poultry Products Technology. $2^{\text {nd }}$ Edition. The Avi Publishing Co., Inc, Westport, Connecticut

Steel R.G.D., Torrie J.H., 1980. Principles and Procedures of Statistics. $2^{\text {nd }}$ Edition. McGraw Hill, New-York

\section{STRESZCZENIE}

\section{Reakcja kurcząt brojlerów na ograniczenie paszy w okresic odchowu w warunkach tropikainych}

Badano wpływ ograniczenia ilości podawanej paszy od 5 do 8 lub 9-go dnia życia kurcząt na ich dalszy rozwój. Dwicście kurcząt podziclono losowo na 4 grupy; w dwóch grupach kurczęta otrzymywały standardowy starter od 0 do 4 dnia życia, po czym były głodzone przez 3 (grupa T1) lub 4 dni (grupa T2). Kurczçta grupy T3 żywiono rozdrobnionym ziarnem kukurydzy do 4 dnia życia i następnie głodzono przez 3 dni. Po tym okresie kurczęta tych 3 grup otrzymywaly standardowy starter i finiszer. Ptaki grupy kontrolnej (TO) żywiono standardowymi dietami dla brojlerów przez cały okres doświadczenia. Ograniczenie podawania paszy w pierwszym okresie (starter)spowodowało istotne zmniejszenic przyrostów szczególnie przed 14-ym dniem życia. W 42 dniu życia kurczęta z grup T1 i T2 „odbudowały" masę ciala, żywione do 4 dnia kukurydzą miały niższa $(\mathrm{P}<0,05)$ masę ciała. W następstwie ograniczenia podawania paszy ptaki lepiej ją wykorzystywały $(\mathrm{P}<0,01)$ niż kurczęta kontrolne, co wskazuje na kompensację wzrostu, nie stwierdzono przy tym wpływu czynnika doświađczalncgo na jakość tuszek.

W podsumowaniu stwierdzono, że kurczęta moga być pozbawione paszy przez 3 lub 4 dni we wezesnym okresie życia bez ujemnego wpływu na ich dalszy rozwój i że jakość paszy podawanej przed głodzeniem i długość okresu głodzenia wpływają na „wyrównanie” masy ciała. 